DOI 10.18551/rjoas.2019-01.66

\title{
THE ROLE OF NUTRIENTS IN IMPROVING THE YIELD OF STRAWBERRY PLANTS
}

\author{
Susilowati Yulia Eko \\ Faculty of Agriculture, University of Tidar, Indonesia \\ E-mail: yuliaekosusilowati@gmail.com
}

\begin{abstract}
The research aims at studying the kinds of nutrients and interval given on the yield of strawberry plants. This research was conducted at Mendirat Village, District of Kranggan, Temanggung Regency, Indonesia, from June until to September 2017 and March until to September 2018. Two treatment factors were arranged in Randomized Complete Block Design with three replications. The first factor was the kinds of nutrients of seven levels i.e. rice water, MSG, shrimp paste, brown sugar, brown sugar and rice water, brown sugar and MSG, and brown sugar and shrimp paste. The second factor was the interval in applying the treatment, which consisted of two levels,, i.e. every 5 days and every 10 days. The result of this research showed that the kinds of nutrients with brown sugar and shrimp paste and interval given of 10 days produced the hight yield weight of fruit per plant and weight per fruit.
\end{abstract}

\section{KEY WORDS}

Nutrients, interval, strawberry, yield.

Strawberry plants (Fragaria $x$ ananassa Duchesne) are not native to Indonesia. It is good for our health. Apart from containing vitamins and minerals, strawberries, especially the seeds and leaves, contain ellagic acid, which acts as an anti-carcinogen and anti-mutagen important for human health. Ellagic acid is a compound of phenol potential as a cancer inhibitor due to hazardous chemical compounds (Suprihatin and Saraswati, 2005). This plant comes from the Chile region planted in sub-tropical climates. Until now, the strawberry center is still limited in the highland areas of Cipanas, Cianjur, and Lembang (Bandung), Batu (Malang), and Bedugul (Bali) (Widyaningsih, 1997).

The average strawberry yield per plant is $1-2 \mathrm{~kg}$ of fruit/year, so it is much lower when compared to its yield in the origin area, which can reach up to 3-5 kg for the Joliette variety (Khanizadeh et al., 1996). This is caused by the rather low percentage of flower formation into fruits, which is only $50 \%$ to $60 \%$, and the fruit formed is small, so the yield is low; this may be related to cultivation that has not been carried out optimally although many methods have been in practice. Cultivation techniques such as planting, irrigation, fertilizing, pruning, and pest control can determine the yield and quality of strawberries (Cahyono, 2011).

In general, agricultural land does not contain enough nutrients for plants, so it is necessary to add nutrients in the form of organic fertilizers (Anonymous, 1986). According to Prihmantoro (1999), the use of organic fertilizers is better when compared to inorganic fertilizers, since the later can lead to soil damage, i.e. making the soil structure becomes hard, if used continuously.

The use of materials that benefit the soil such as rice water, shrimp paste, and Javanese traditional brown sugar is one example of the concept of low input technology in handling soil fertility (Alibasyah, 2000). The success of strawberry cultivation (Fragaria chiloensis $L$.) is very dependent on the presence of soil organic matter, because soil organic matter is able to influence the physical, chemical, and biological properties of the soil (Wardhani, 2010).

The influence on the physical properties of the soil is improving soil structure and increasing the absorption of groundwater. The influence on the biological nature of the soil is to increase the activity of microorganisms in converting organic matter into forms available to plants. The effect on soil chemical properties is to increase nutrient content and cation 
exchange capacity, so nutrient for plants become available (Darmawijaya, 1990). Fertilization can increase soil fertility to increase yields both in quantity and quality.

What need to be considered in the use of these materials is the intervals to be in accordance with the needs of the plant. Provision of fertilizers with excessive doses will result in inefficient fertilization (Anonymous, 2007). Less fertilizer than recommended will result in less optimal growth and will affect plant physiology (Sumaryo, 1993). Fertilizer interval is needed to add required nutrients because it will affect photosynthesis that affects plant growth and development.

\section{METHODS OF RESEARCH}

The research was in the form of a pot experiment using a Complete Randomized Block Design, which was arranged in Factorial $(7 \times 2)$. The study used three (3) replications as blocks. The first factor was the type of nutrients consisting of 7 levels: rice water, MSG, shrimp paste, brown sugar, brown sugar and rice water, brown sugar and MSG, brown sugar and shrimp paste. The second factor was the interval of applying the treatment consisting of 2 levels: once every 5 days and 10 days.

\section{RESULTS AND DISCUSSION}

Variance shows that the types of nutrients do not significantly affect the time of flowering, number of flower bunches, number of flowers, number of fruits, acidity content, and vitamin $\mathrm{C}$ content (Figures 1, 2, 3, 4, 10,11). However, the types of nutrients cause very significant differences in fruit weight per plant, weight per fruit, and sugar content (Figures 5, $6,9)$ and there has been interaction between types of nutrients and treatment intervals on fruit weight per plant and weight per fruit (Figure 7, 8). The combination of types and intervals do not cause significant differences for the acidity and vitamin $\mathrm{C}$ content (Figures $10,11)$.

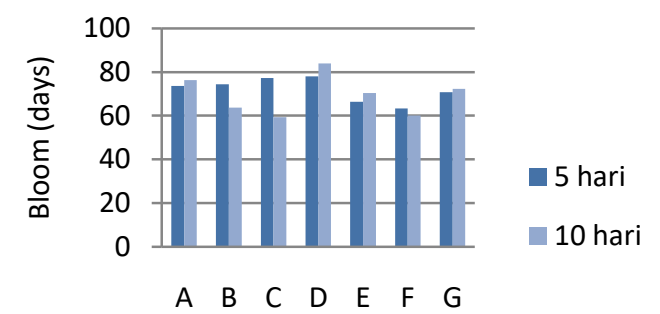

Types of Nutrition

Figure 1 - Bloom on different nutrients types and different treatment intervals

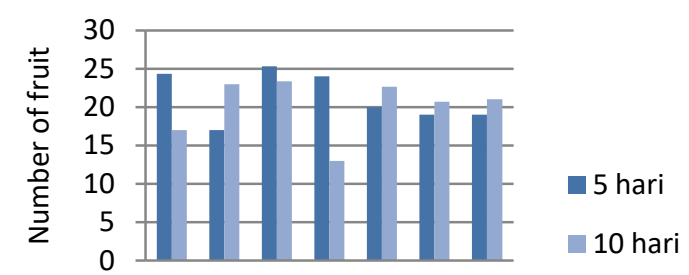

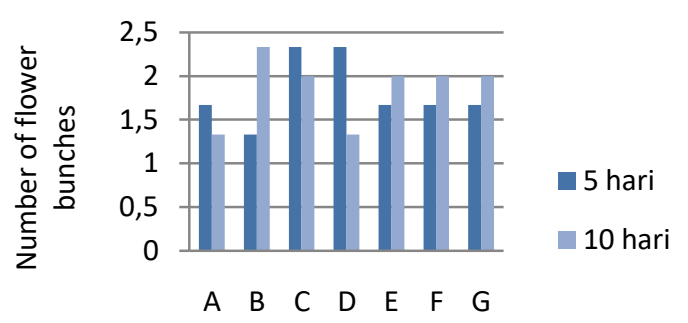

Types of Nutrition

Figure 2 - Number of flower bunches on different nutrients types and different treatment intervals

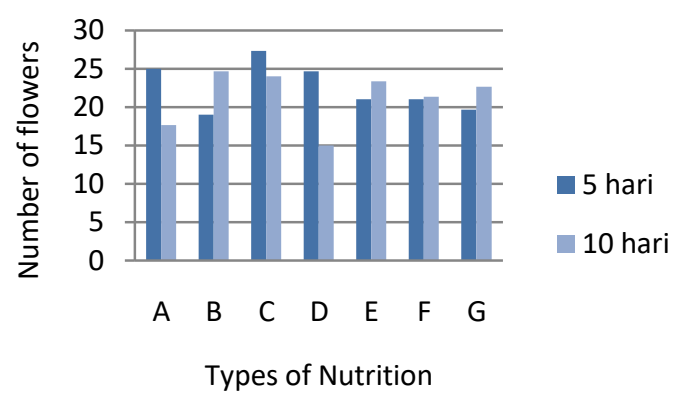

Figure 4 - Number of flowers on different nutrients types and different treatment intervals
Figure 3 - Number of fruit on different nutrients types and different treatment intervals 


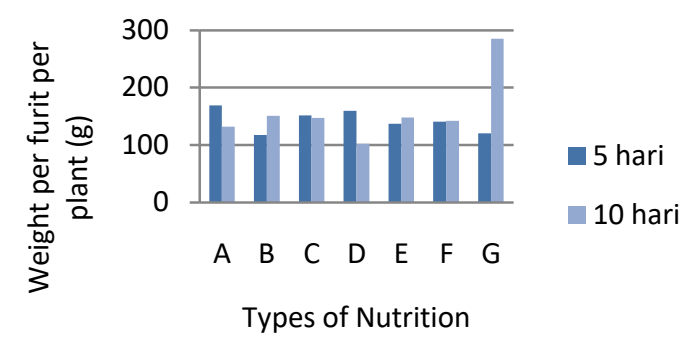

Figure 5 - Weight per fruit per plant on different nutrients types and different treatment intervals

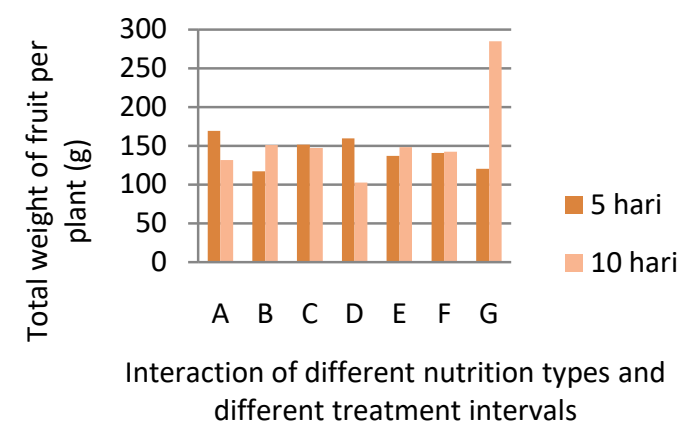

Figure 7 - Interaction of different nutrients types and different treatment intervals on total weight of fruit per plant

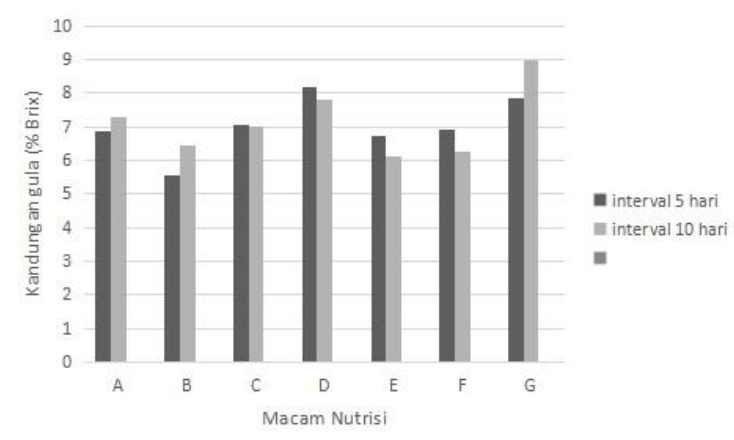

Figure 9 - Sugar content (\% Brix) on different nutrients types and different treatment intervals

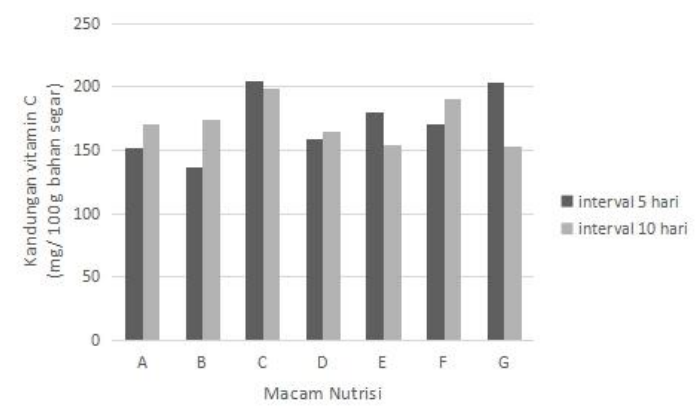

Figure 11 - Vitamin $C$ content $(\mathrm{mg} / 100 \mathrm{~g}$ of fresh fruit) on different nutrients types and different treatment intervals

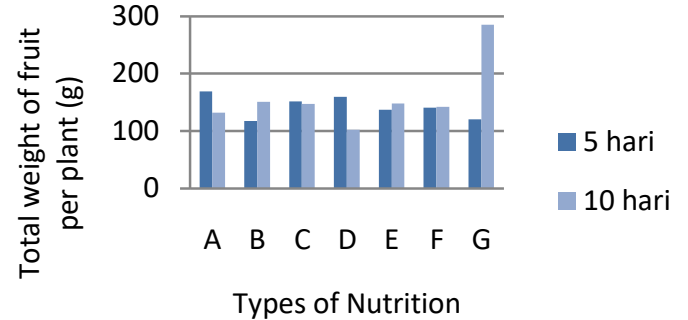

Figure 6 - Total weight of fruit per plant on different nutrients types and different treatment intervals

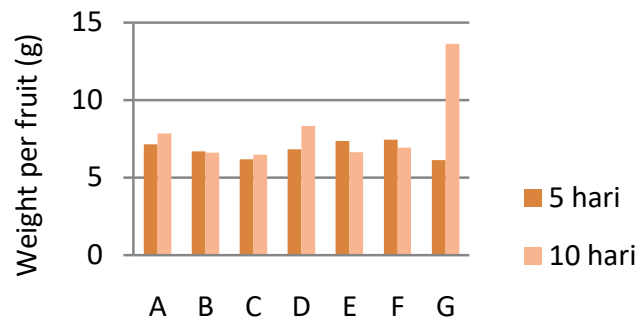

Interaction of different nutrition types and different treatment intervals

Figure 8 - Interaction of different nutrients types and different treatment intervals on weight per fruit

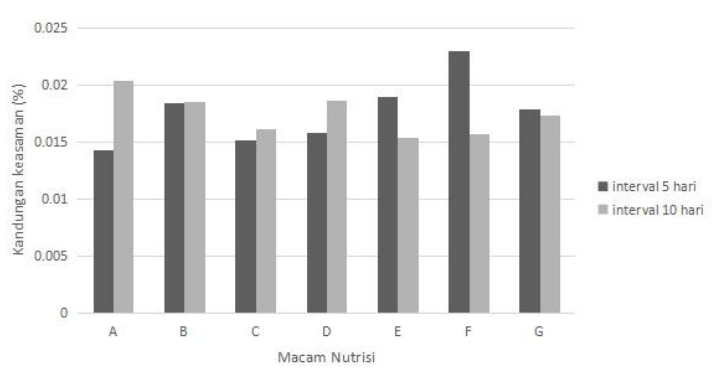

Figure 10 - Acid content (\%) on different nutrients types and different treatment intervals

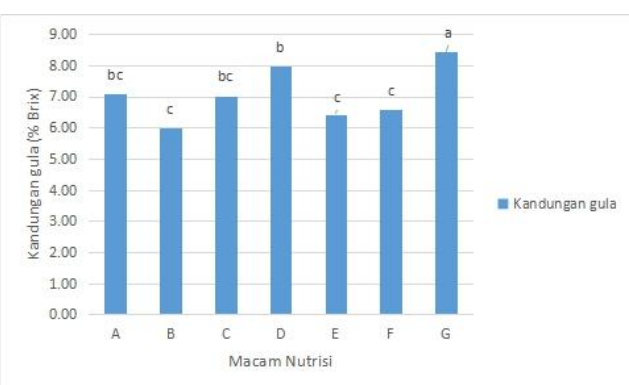

Figure 12 - Average sugar content (\% Brix) on different nutrients types 


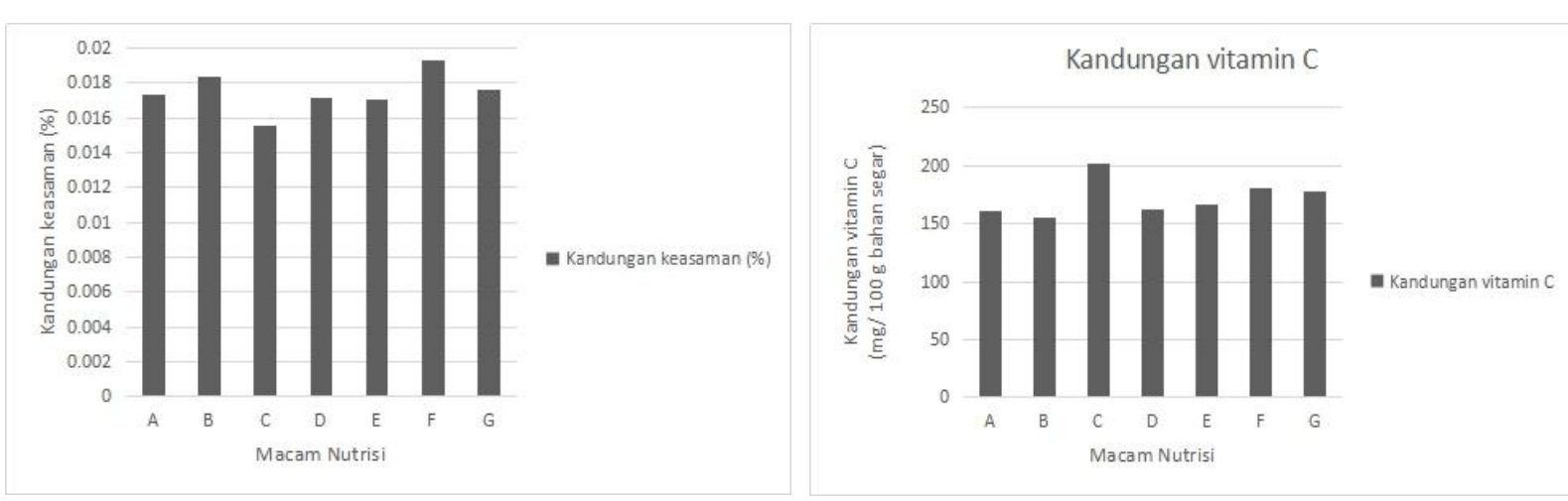

Figure 13 - Average sugar content (\% Brix) on different nutrients types
Figure 14 - Average vitamin C content (mg/100 g of fresh fruit) on different nutrients types

Notes on figures: A - Rice water; E - Brown sugar and rice water; B - MSG; F - Brown sugar and MSG; C - Shrimp paste; G - Brown sugar and shrimp paste; D - Javanese brown sugar.

Types of nutrients do not significantly cause differences for the time of flowering, number of flower bunches, number of flowers, and number of fruits. Different nutrient types show similar response related to flowering, the number of flower bunches, the number of flowers, and the number of fruits. This is because nutrients, other than the brwon sugar and shrimp paste, have less nutrient content, so it produces low photosynthate during photosynthesis mainly used for plant growth. Photosynthate formed with treatments other than the combination of brown sugar and shrimp paste gives the same results for flowering, number of flower bunches, number of flowers, and number of fruits.

Further DMRT $5 \%$ testing on types of nutrients gives significantly different results on fruit weight per plant and weight per fruit (Figure 5,6). The highest fruit weight per plant is 285.04 grams and the highest weight per fruit is 9.87 grams for the brown sugar and shrimp paste. The brown sugar contains high carbohydrates, crude protein (fiber), minerals, vitamin $\mathrm{A}$, vitamin E, vitamin B12, folic acid, ascorbic acid, riboflavin, lactoflavine, $\mathrm{Fe}, \mathrm{Ca}$, and carotene. It comes from coconut sap so it contains a lot of cytokines. Cytokines are a growth regulator that plays a role in cell differentiation, stimulating plant growth.

Shrimp paste is one of the salting fermented products of fish or shrimp. 100 grams of shrimp paste, according to Suprapti (2001), contains 30.0 grams protein, 3.5 grams fat, 3.5 grams carbohydrate, 23.0 grams minerals, $100.0 \mathrm{mg}$ calcium, $250.0 \mathrm{mg}$ phosphorus, $3.1 \mathrm{mg}$ iron, and 40.0 grams water. Shrimp paste is an organic fertilizer, so it can improve soil physical, soil chemistry, and soil biology.

Fertilizers containing phosphorus elements are important for plant generative growth, namely root growth, flower formation, fruit formation, seed formation, and fruit ripening (Darmawijaya, 1990). Shrimp paste contains large phosphorus.

Phosphorus in plants acts as a constituent of cell nuclei; it is also important in cell division and development of meristematic tissue and is needed for the formation of carbohydrates and for the efficiency of the chloroplast activity and metabolic activity (Wilkins, 1984). Plants need phosphorus the most during root growth, flower, and fruit formation (Anonymous, 2007).

Sugar and shrimp paste as organic fertilizers can improve soil fertility both physically, chemically, and biologically. These results in the soil structure becoming loose or crumbly, as nutrients are added, leading to the increase in the activity of microorganisms, so nutrients become available and can be absorbed by plants. As nutrients increases, the photosynthesis processes become better, photosynthate formed increase, and fruit formation also increases, thus increasing the weight of the fruit per plant and making the fruit bigger (Wilkins, 1984). Bigger fruit sizes result in increased fruit weight leading to higher levels of substances in the tissues such as vitamin C, sugar, water, carbohydrates, proteins, and minerals. This is in accordance with the study of Susilowati et al. (2017), that treatment of 
brown sugar and shrimp paste on strawberry plants providing the highest sugar and vitamin C content.

Further DMRT 5\% testing on types of nutrients gives significantly different results. Brown sugar and shrimp paste provide the highest sugar content of $8.42 \%$ Brix. The brown sugar contains high carbohydrates, crude protein (fiber), minerals, vitamin $A$, vitamin $E$, vitamin $\mathrm{B} 12$, folic acid, ascorbic acid, riboflavin, lactoflavine, $\mathrm{Fe}, \mathrm{Ca}$, and carotene. It comes from coconut sap so it contains a lot of cytokines. Cytokines are a growth regulator that plays a role in cell differentiation, stimulating plant growth.

The brown sugar and shrimp paste as organic fertilizers can improve soil fertility physically, chemically, and biologically (Alibasyah, 2000), resulting in the soil structure becoming loose or crumbly, as nutrients are added, leading to the increase in the activity of microorganisms, so nutrients become available and can be absorbed by plants. As nutrients increases, the photosynthesis processes become better and photosynthate formed increase as well. Thus, more carbohydrates are formed so that it can increase the sugar content in strawberries and make strawberries taste sweeter.

Organic fertilizers are generally complete, meaning they contain essential macro and micro nutrients even in small amounts. Organic fertilizer must not only be given once but should be repeated many times according to plant needs (Herlambang, 2001).

The highest sugar content is for fruit treated with nutrients from brown sugar $(7.89 \%$ Brix), followed by rice water (7.07\% Brix), and shrimp paste $(7.02 \%$ Brix); yet, the figures are not significantly different, as only one type of nutrient is used. This is different from using two types of nutrients, namely brown sugar and shrimp paste--it can provide the highest sugar content.

Treatment Intervals. Variance shows that the treatment intervals do not significantly affect the time of flowering, number of flower bunches, number of flowers, number of fruits, acidity content, and vitamin $\mathrm{C}$ content (Figures 1, 2, 3, 4, 10,11). With treatment intervals of 5 days and 10 days, the same response is obtained for all aspects. However, the intervals lead to significantly different results for fruit weight per plant and weight per fruit (Fig. 5-6).

Further DMRT 5\% testing shows that treatment intervals do not significantly affect fruit weight and weight per fruit. The ten-day interval gives the highest weight on fruit weight per plant of 158.30 grams and weight per fruit of 8.06 grams. The brown sugar and shrimp paste as an organic fertilizer decomposed in a rather long time so the ten-day interval has helped to make nutrients available. Available nutrients can be absorbed by plants (Sumaryo, 1993).

Organic fertilizers contain smaller amount of macro and micro nutrients compared to inorganic fertilizers. Organic fertilizers have slow release properties, so the nutrients available for plants can be fulfilled for a long time, leading to good sustainability (Sumaryo, 1993). Therefore, organic fertilizers must be applied repeatedly so nutrient can be fulfilled for plant growth and development. The interval is influenced by the phase of plant growth (Wilkins, 1984). At the intervals, the nutrients needed for plant growth and development can be fulfilled, so the same response happen to flowering, number of flower bunches, number of flowers, number of fruits, sugar content, acidity content, and vitamin C.

Organic fertilizers are generally complete, meaning they contain essential macro and micro nutrients even in small amounts. Organic fertilizer must not only be given once but should be repeated many times according to plant needs (Herlambang, 2001).

Interactions between nutrients and treatment intervals. There has been no significant difference on the interaction between nutrients and treatment intervals for flowering, number of flower bunches, number of flowers, number of fruits, acidity content, and vitamin $\mathrm{C}$ content (Figures 1, 2, 3, 4, 10, 11); the same response is obtained for all aspects.

The interaction between nutrients and treatment intervals significantly affect for fruit weight per plant and weight per fruit. Further DMRT 5\% testing on the interaction of the administration of brown sugar and shrimp paste in the ten-day interval gives the highest results on fruit weight (285.04 grams) and weight of fruit per plant (13.61 grams) (Fig. 7-8).

The brown sugar and shrimp paste as an organic fertilizer decomposed in a rather long time so the ten-day interval has helped to make nutrients available. Available nutrients can be absorbed by plants leading to high fruit weight and fruit weight per plant. 


\section{CONCLUSION}

Brown sugar and shrimp paste and the 10-day nutrition interval provide the highest yield on fruit weight per plant, weight per fruit, and sugar content. The combination of brown sugar, shrimp paste, and the ten-day interval gives the highest yield on fruit weight per plant and weight per fruit.

\section{REFERENCES}

1. Alibasyah, M. 2000. Peranan Bahan Organik Untuk Menunjang Pertanian Berkelanjutan pada Lahan Kering. Topik Khusus. Program Pasacasarajana. UNPAD, Bandung.

2. Anonim. 1986. Menuju Pemupukan Berimbang guna Meningkatkan Jumlah and Mutu Hasil Pertanian. Direktorat Jendral Tanaman Pangan. Direktorat Penyuluhan Tanaman Pangan. $49 \mathrm{~h}$.

3. 2007. Stroberi sebagai Antioksidan. Trubus. 36 (?): $143 \mathrm{~h}$.

4. Cahyono, B. 2011. Sukses Budidaya Stroberi di Pot and Perkebunan. Lily Publisher. Yogyakarta. $96 \mathrm{~h}$.

5. Darmawijaya, I. 1990. Klasifikasi Tanah, Dasar Teori bagi Peneliti Tanah and Pelaksanaan Pertanian. UGM. Yogyakarta. $411 \mathrm{~h}$.

6. Herlambang, S.S. 2001. Peranan pertanian organik dalam pembangunan pertanian berkelanjutan. Jurnal Wimaya. Yogyakarta. No XIX (32): 26-28.

7. Khanizadeh, S., D. Buszard, O. Carries and P.O. Thibodeau. 1996. Joliette Strawberry. Plant Science 31 (6); 1036 - 1037. Canada.

8. Medina, $L$ and Miranda. 2007. Strawberry Production from Transplants Fumigated with Methyl Bromide Alternatives. Hort. Sci. 5 (3): 407 - 416.

9. Prihmantoro. 1999. Memupuk Tanaman Sayuran. Penebar Swadaya. Jakarta. $52 \mathrm{~h}$.

10. Rohmayati, M. 2013. Budidaya Stroberi Di Lahan Sempit. Infra Pustaka. 122 h.

11. Rukmana, R. 1999. Stroberi. Budidaya and Pasca Panen. Kanisius. Yogyakarta. 79 h.

12. Sumaryo. 1993. Pengantar Ilmu Kesuburan Tanah. Fakultas Pertanian. Universitas Sebelas Maret. Surakarta. $84 \mathrm{~h}$.

13. Supriatin, B and D Saraswati. 2005. Berkebun Stroberi Secara Komersil. Penebar Swadaya. Jakarta. $107 \mathrm{~h}$.

14. Suprapti., M.L, 2001. Membuat Terasi. Kanisius, Yogyakarta.

15. Wardhani, I.K. 2010.Pertumbuhan, Hasil, and Nilai Gizi Stroberi melalui Peningkatan Slurry Biogas and Pupuk Kandang. Agric 22 (1): 1-8

16. Widyaningsih Saumadi. 1997. Budidaya Stoberi di Pot and Kebun. Aneka. Bogor. $71 \mathrm{~h}$.

17. Wilkins, M.B. 1984. Advanced Plant Physiology. Pitman Publishing Limited. London. $512 \mathrm{p}$.

18. Susilowati, Y.E., R. Sarwitri and Marlina, P.S. 2017. Nutrisi Meningkatkan Kualitas Hasil Tanaman Stroberi. Fakultas Pertanian Universitas Tidar. $43 \mathrm{~h}$. 